\title{
HUBUNGAN STRES KERJA, STATUS GIZI, DAN SINDROM METABOLIK PADA KARYAWAN LAKI-LAKI DEWASA
}

\author{
Sutadarma IWG'; Purnawati S²; dan Ruma IMW'1 \\ ${ }^{1}$ Bagian Biokimia Fakultas Kedokteran Universitas Udayana \\ ${ }^{2}$ Bagian Fisiologi Fakultas Kedokteran Universitas Udayana
}

\begin{abstract}
ABSTRAK
Penelitian ini bertujuan mengetahui hubungan antara tingkat stres kerja dan status gizi dengan risiko sindrom metabolik pada karyawan laki-laki dewasa. Rancangan penelitian ini adalah potong lintang. Pengambilan sampel dilakukan berdasarkan purposive sampling. Penelitian dilakukan pada karyawan bank X di kota Denpasar. Sebanyak 32 orang ikut serta dari 35 orang karyawan laki-laki dewasa yang memenuhi kriteria penelitian. Data yang diambil meliputi usia, aktivitas fisik, merokok, minum alkohol, indeks massa tubuh, lingkar lengan atas, lingkar perut, tebal lemak trisep, tebal lemak suprailiaka, kadar glukosa puasa, $\mathrm{HDL}$ dan trigliserida. Analisis data menggunakan uji korelasi dengan batas kemaknaan $5 \%$. Median usia subyek penelitian adalah $42(25-46)$ tahun dengan rerata IMT adalah obese I $\left(27,49 \mathrm{~kg} / \mathrm{m}^{2}\right)$. Median tingkat stres subyek penelitian adalah ringan (nilai 62,5) dengan indeks aktivitas fisik tergolong kategori cukup. Didapatkan hubungan negatif lemah antara tingkat stres dengan sindrom metabolik yang secara statistik tidak signifikan.Didapatkan hubungan negatif sedang antara berat badan $(p=0,025)$, tinggi badan $(p=0,003)$ dan tebal lemak suprailiaka $(p=0,014)$ dengan kadar HDL yang secara statistik signifikan.Didapatkan hubungan positif kuat antara lingkar perut dan kadar trigliserida yang secara statistik signifikan $(p=0,035)$. Didapatkan hubungan positif sedang antara berat badan $(p=0,024)$, IMT $(p=0,018)$ dan lingkar perut $(p=0,009)$ dengan rasio trigliserida dan HDL yang secara statistik signifikan dimana rasio tersebut merupakan indikator pembentukkan plak aterosklerosis. Hubungan status gizi dengan risiko sindrom metabolik secara statistik signifikan namun belum dapat dikatakan mendukung secara klinis karena minimal tiga faktor risiko harus terpenuhi.
\end{abstract}

Kata kunci: laki-laki dewasa, stres, status gizi, sindrom metabolik

\section{ABSTRACT}

\section{THE CORRELATION BETWEEN OCCUPATIONAL STRESS, NUTRITIONAL STATUS, TO METABOLIC SYNDROME IN ADULT MALE WORKERS}

The objective of the study is to investigate the correlation of work stress index, nutritional status, and metabolic syndrome in adult male workers. The study was applied using a cross-sectional method.Thirty two subjects joined from thirty five subjects which were selected using certain criteria. The study was conducted among workers at Bank X in Denpasar. Data collection covered for age, physical activity, body mass index, mid upper arm circumstance, abdomen circumstance, tricep skinfold, suprailiaca skinfold, glucosa, high density lipoportein (HDL), and trigliseride levels. Statistical analysis used correlation test and the level of significance was $5 \%$. Median of age was 42 (25-46) years old, and average of BMI was obese I $\left(27,49 \mathrm{~kg} / \mathrm{m}^{2}\right)$. The result showed that median of stress index was low (score 62,5$)$, and physical activity index was moderate. The correlation between stress index and metabolic syndrome were not significant. Meanwhile, negative correlation were significant between weight $(p=0,025)$, height $(p=0,003)$, suprailiaca skinfold $(p=0,014)$, and HDL levels. Abdomen circumstance was significantly correlated with trigliseride levels $(p=0,035)$. There were also found a significant correlation between weight $(p=0,024)$, body mass index $(p=0,018)$, abdomen circumstance $(p=0,009)$, and trigliseride HDL ratio which is indicated as a ratio as plaque atherosclerosis in blood. The correlation between nutritional status and metabolic syndrome was significant statistically but there was no clinical implication because at least three risk factors must be existed.

Keywords :adult male worker, stress index, nutritional status, metabolic syndrome

\section{PENDAHULUAN}

eban karyawan yang terus meningkat dan waktu kerja yang semakin padat merupakan salah satu penyebab timbulnya stres di tempat kerja. Stres kerja berhubungan dengan kejadian kegemukan, karena stres kerja mengubah pola makan menjadi tidak sehat, kurang berolahraga, dan akhirnya akan meningkatkan berat badan. ${ }^{1}$ 
Penyebab kegemukan belum sepenuhnya diketahui, namun diduga berhubungan dengan faktor biologis dan faktor lingkungan. Prevalensi kegemukan di dunia saat ini cenderung meningkat. Kegemukan telah diketahui sebagai salah satu faktor risiko terjadinya sindrom metabolik. ${ }^{2}$

Prevalensi sindrom metabolik didapatkan sebesar 68 persen pada karyawan yang mengalami stres secara kronis dan prevalensinya lebih tinggi pada laki-laki dibandingkan perempuan. ${ }^{3}$ Berdasarkan National Cholesterol Education Program (NCEP) Adult Treatment Panel III (ATP III), faktor-faktor risiko sindrom metabolik meliputi obesitas sentral, dislipidemia (kadar trigliserida tinggi; kadar high-density lipoprotein/HDL rendah), tekanan darah tinggi, resistensi insulin (kadar glukosa puasa tinggi), keadaan protrombosis dan proinflamasi (kadar fibrinogen tinggi; kadar C-reactive protein/CRP tinggi). Diagnosis sindrom metabolik dapat ditegakkan apabila terdapat tiga atau lebih faktor risiko. ${ }^{4}$

Penelitian Chandola, dkk. mengenai hubungan stres kerja dan sindrom metabolik 10.308 orang subyek yang diikuti selama 14 tahun,didapatkan terdapat hubungan stres kerja dan risiko sindrom metabolik. Paparan stres kerja yang kronis merupakan risiko yang besarnya lebih dari dua kali untuk terjadi sindrom metabolik (OR 2,25; 95\% Cl:1,31-3,85). Hasil penelitian menunjukkan bahwa stres kerja merupakan faktor risiko penting terjadinya sindrom metabolik. ${ }^{3}$

Stres kerja dapat menimbulkan perubahan metabolisme tubuh yang kemudian dapat menimbulkan perubahan parameter status gizi. Penelitian Kouvonen, dkk. mengenai hubungan stres kerja dan indeks massa tubuh (IMT) sebagai parameter status gizi pada 45.810 orang subyek, didapatkan hubungan lemah antara stres kerja ringan dengan IMT tinggi. Hasil penelitian menunjukkan terdapat hubungan lemah antara stres kerja dan IMT. ${ }^{5}$

Berbagai faktor dapat mempengaruhi keadaan stres kerja, status gizi dan sindrom metabolik antara lain jenis kelamin laki-laki, usia dewasa (30-55 tahun), sudah menikah, merokok, minum alkohol, aktivitas fisik rendah dan terikat kontrak kerja. ${ }^{6-8}$ Oleh karena itu penelitian ini bertujuan untuk mempelajari hubungan antara tingkat stres kerja dan status gizi dengan risiko sindrom metabolik pada karyawan laki-laki dewasa.

\section{METODE PENELITIAN}

\section{Subyek Penelitian}

Rancangan penelitian adalah potong lintang untuk mengetahui hubungan antara stres kerja, status gizi, dan sindrom metabolik pada karyawan laki-laki dewasa. Subyek penelitian adalah karyawan laki-laki dewasa usia 25-55 tahun yang memenuhi kriteria sebagai subyek penelitian secara purposive. ${ }^{9}$ Sebanyak 32 orang dari 35 subyek menyatakan bersedia mengikuti penelitian dengan memberikan pernyataan persetujuan sebelumnya. Penelitian ini telah mendapatkan persetujuan dari pihak bank tempat karyawan bekerja.

\section{Pengumpulan data}

Pengumpulan data dilakukan pada minggu keempat bulan Juli pada karyawan bank $\mathrm{X}$ di kota Denpasar. Berdasarkan prosedur penelitian, dilakukan wawancara mengenai karakteristik demografi meliputi usia, tingkat pendidikan, status perkawinan, aktivitas fisik ${ }^{10}$, kebiasaan merokok dan minum alkohol. Selanjutnya dilakukan pemeriksaan tingkat stres, status gizi dan faktor risiko sindrom metabolik. Pemeriksaan tingkat stres dilakukan dengan metoda kuesioner, di mana subyek diminta mengisi kuesioner tingkat stres yang telah disediakan. ${ }^{11}$ Pemeriksaan status gizi meliputi berat badan, tinggi badan, tebal lemak trisep dan suprailika, lingkar perut dan lingkar lengan atas. ${ }^{12}$ Pemeriksaan faktor risiko sindrom metabolik meliputi tekanan darah, kadar glukosa darah puasa, kadar trigliserida dan HDL pada pagi hari dengan terlebih dahulu subyek penelitian diminta untuk puasa 10-12 jam sebelumnya untuk mengurangi bias pemeriksaan. Pada saat pemeriksaan didapatkan empat orang subyek tidak melakukan puasa sebelumnya, sehingga pemeriksaan laboratorium ditunda keesokan harinya.

\section{Analisis Data}

Analisis data dilakukan dengan menggunakan program Statistical Package for Social Science (SPSS versi 11.5). Normalitas 
data diuji dengan tes Kolmogorov-Smirnov. Uji kemaknaan hubungan antar variabel secara statistik digunakan uji korelasi, dengan batas kemaknaan sebesar $5 \%$.

\section{HASIL}

Median dan minimum-maksimum usia subyek penelitian adalah 42 (25-46) tahun.
Tingkat pendidikan subyek sebagian besar adalah sarjana sebanyak 28 orang $(87,5 \%)$ sedangkan sisanya sebanyak empat orang $(12,5 \%)$ adalah lulusan sekolah menengah umum. Berdasarkan status perkawinan, hampir sebagian besar subyek sudah menikah yaitu sebanyak 30 orang $(93,75 \%)$ dan sisanya dua orang $(6,25 \%)$ belum menikah. Secara rinci dapat dilihat pada Tabel 1.

Tabel 1

Sebaran Karakteristik Data Dasar Subyek Penelitian

\begin{tabular}{lc}
\hline \multicolumn{1}{c}{ Variabel } & Nilai \\
\hline Usia (tahun) & $42(25-46)^{\#}$ \\
Aktivitas fisik & $32(2-48)^{\#}$ \\
Berat Badan (kg) & $77,75(57,20-113,00)^{\#}$ \\
Tinggi badan (cm) & $167,20 \pm 5,89$ \\
IMT (kg/m²) & $27,49 \pm 3,39$ \\
Tebal lemak trisep (mm) & $13,23 \pm 4,72$ \\
Tebal lemak suprailiaka (mm) & $26,06 \pm 8,45$ \\
Lingkar lengan atas (cm) & $29,26 \pm 2,33$ \\
Lingkar perut (cm) & $89,43 \pm 9,96$ \\
Tingkat stres & $62,5(50-102)^{\#}$ \\
Kadar glukosa puasa (g/dL) & $92(77-349)^{\#}$ \\
Kadar HDL (mg/dL) & $41,81 \pm 8,81$ \\
Kadar trigliserida (mg/dL) & $167(68-375)^{\#}$ \\
Rasio HDL dan trigliserida & $4,56 \pm 1,92$ \\
Sistolik (mm Hg) & $116,96 \pm 14,22$ \\
Diastolik (mm Hg) & $79,16 \pm 10,99$ \\
\hline${ }^{*}=$ bermakna; \#= median(minimum-maksimum)
\end{tabular}

Hanya delapan orang dari 32 subyek (25\%) yang aktif merokok dengan jumlah 2-4 batang per hari, sedangkan 24 orang lainnya $(75 \%)$ tidak merokok. Demikian juga halnya dengan minum alkohol, hanya dua orang subyek $(6,25 \%)$ yang kadang-kadang minum alkohol sedangkan subyek lainnya tidak minum alkohol sama sekali. Sebanyak 23 orang subyek $(78,88 \%)$ memiliki indeks aktivitas fisik cukup, dan hanya 9 orang subyek $(21,12 \%)$ memiliki tingkat indeks aktivitas fisik rendah. Dari Tabel 2 dapat dilihat adanya hubungan negatif lemah antara tingkat stres dan sindrom metabolik, namun secara statistik tidak signifikan.

Tabel 2

Hubungan Tingkat Stres dengan Parameter Sindrom Metabolik

\begin{tabular}{|c|c|c|c|c|c|c|}
\hline Variabel & & Glukosa & HDL & Trigliserida & Sistolik & Diastolik \\
\hline \multirow{2}{*}{ Stres } & $r$ & $-0,180$ & $-0,112$ & $-0,040$ & $-0,110$ & $-0,094$ \\
\hline & $p$ & 0,325 & 0,543 & 0,828 & 0,548 & 0,610 \\
\hline
\end{tabular}


Tabel 3 menunjukkan adanya hubungan negatif sedang antara berat badan dengan kadar $\mathrm{HDL} \quad(p=0,025)$. Berdasarkan tinggi badan, didapatkan hubungan negatif kuat antara tinggi badan dan kadar HDL $(p=0,003)$.
Sementara itu berdasarkan IMT, didapatkan hubungan lemah antara IMT dan variabel parameter sindrom metabolik, yang secara statistik tidak signifikan.

Tabel 3

Hubungan Berat Badan, Tinggi Badan, IMT dengan Parameter Sindrom Metabolik

\begin{tabular}{lcccccc}
\hline Variabel & & Glukosa & HDL & Trigliserida & Sistolik & Diastolik \\
\hline \multirow{2}{*}{ Berat badan } & $\mathrm{r}$ & 0,179 & $-0,396$ & 0,246 & 0,032 & 0,135 \\
\cline { 2 - 7 } & $\mathrm{p}$ & 0,328 & $0,025^{*}$ & 0,828 & 0,862 & 0,462 \\
\hline \multirow{2}{*}{ Tinggi badan } & $\mathrm{r}$ & $-0,167$ & $-0,505^{\mathrm{P}}$ & $-0,141$ & $-0,260^{\mathrm{P}}$ & $-0,208^{\mathrm{P}}$ \\
\cline { 2 - 7 } & $\mathrm{p}$ & 0,362 & $0,003^{*}$ & 0,443 & 0,151 & 0,253 \\
\hline \multirow{2}{*}{ IMT } & $\mathrm{r}$ & 0,266 & $-0,222^{\mathrm{P}}$ & 0,272 & $0,058^{\mathrm{P}}$ & $0,191^{\mathrm{P}}$ \\
\cline { 2 - 6 } & $\mathrm{p}$ & 0,140 & 0,223 & 0,132 & 0,753 & 0,295 \\
\hline
\end{tabular}

*= bermakna; $r=$ korelasi pearson; $p=$ tingkat kemaknaan 0,05

Tabel 4

Hubungan Lingkar Lengan Atas, Lingkar Perut, Tebal Lemak Trisep dan Tebal Lemak Suprailiakan dengan Sindrom Metabolik

\begin{tabular}{lcccccc}
\hline \multirow{2}{*}{ Variabel } & & Glukosa & HDL & Trigliserida & Sistolik & Diastolik \\
\hline \multirow{2}{*}{ Lingkar Lengan Atas } & $\mathrm{r}$ & 0,150 & $-0,108^{\mathrm{P}}$ & 0,187 & $0,045^{\mathrm{P}}$ & $0,096^{\mathrm{P}}$ \\
\cline { 2 - 7 } & $\mathrm{p}$ & 0,412 & 0,555 & 0,307 & 0,806 & 0,602 \\
\hline \multirow{2}{*}{ Lingkar Perut } & $\mathrm{r}$ & 0,268 & $-0,332^{\mathrm{P}}$ & 0,374 & $0,094^{\mathrm{P}}$ & $0,223^{\mathrm{P}}$ \\
\cline { 2 - 7 } & $\mathrm{p}$ & 0,113 & 0,063 & $0,035^{*}$ & 0,608 & 0,220 \\
\hline \multirow{2}{*}{ Tebal Lemak Trisep } & $\mathrm{r}$ & 0,121 & $-0,283^{\mathrm{P}}$ & 0,192 & $0,102^{\mathrm{P}}$ & $0,092^{\mathrm{P}}$ \\
\cline { 2 - 7 } & $\mathrm{p}$ & 0,511 & 0,117 & 0,293 & 0,580 & 0,617 \\
\hline \multirow{2}{*}{ Tebal Lemak Suprailiaka } & $\mathrm{r}$ & 0,274 & $-0,431$ & 0,125 & $-0,034^{\mathrm{P}}$ & $-0,041^{\mathrm{P}}$ \\
\cline { 2 - 7 } & $\mathrm{p}$ & 0,192 & $0,014^{*}$ & 0,497 & 0,855 & 0,825 \\
\hline
\end{tabular}

*= bermakna; $r=$ korelasi pearson; $p=$ tingkat kemaknaan 0,05

Tabel 5

Hubungan Rasio Trigliserida dan HDL dengan Status Gizi

\begin{tabular}{|c|c|c|}
\hline \multicolumn{2}{|l|}{ Variabel } & Rasio Trigliserida dan HDL \\
\hline \multirow{2}{*}{ Berat Badan } & $r$ & 0,398 \\
\hline & $p$ & $0,024^{*}$ \\
\hline \multirow{2}{*}{ Tinggi Badan } & $r$ & $0,106^{P}$ \\
\hline & $p$ & 0,565 \\
\hline \multirow{2}{*}{ IMT } & $r$ & $0,415^{P}$ \\
\hline & p & $0,018^{*}$ \\
\hline \multirow{2}{*}{ Lingkar Lengan Atas } & $r$ & $0,209 P$ \\
\hline & p & 0,250 \\
\hline \multirow{2}{*}{ Lingkar Perut } & $r$ & $0,452^{P}$ \\
\hline & p & $0,009^{*}$ \\
\hline \multirow{2}{*}{ Tebal Lemak Trisep } & $r$ & $0,241^{\mathrm{P}}$ \\
\hline & $p$ & 0,184 \\
\hline \multirow{2}{*}{ Tebal Lemak Suprailiaka } & $r$ & $0,256^{\mathrm{P}}$ \\
\hline & $p$ & 0,157 \\
\hline
\end{tabular}


Didapatkan hubungan positif kuat antara lingkar perut dan kadar trigliserida yang secara statistik signifikan $(p=0,035)$, sedangkan berdasarkan tebal lemak suprailiaka, didapatkan hubungan negatif kuat antara tebal lemak suprailiaka dan kadar HDL yang secara statistik signifikan $(p=0,014)$. Secara rinci dapat dilihat pada Tabel 4 .

Selanjutnya didapatkan hubungan positif sedang antara berat badan, IMT $(p<0,05)$ dan lingkar perut $(p<0,05)$ dengan rasio trigliserida dan HDL yang secara statistik signifikan (Tabel 5).

\section{BAHASAN}

Keterbatasan pengukuran tingkat stres dengan metoda kuesioner dalam pelaksanaannya subyek penelitian cenderung kurang teliti dalam mengisi kuesioner karena keterbatasan waktu yang dimiliki. Hal ini menyebabkan hasil pengukuran tingkat stres kemungkinan menjadi bias. Sebelum pemeriksaan laboratorium, subyek penelitian diminta puasa selama 10-12 jam dengan tujuan mengurangi pengaruh faktor makanan yang dikonsumsi, namun terdapat empat orang yang tidak melakukan puasa sehingga pemeriksaan laboratorium diulang.

Didapatkan hubungan negatif lemah antara tingkat stres dan parameter sindrom metabolik yang secara statistik tidak signifikan, artinya didapatkan hubungan terbalik antara tingkat stres dengan sindrom metabolik. Diketahui bahwa stres dalam waktu lama dapat meningkatkan sekresi hormon kortisol sehingga meningkatkan obesitas sentral, resistensi insulin, dan dislipidemia. ${ }^{13-15}$

Pada penelitian ini, pengukuran stres hanya dilakukan sekali dan dalam kuesioner tingkat stres tidak dicantumkan pengukuran lama dan kuatnya paparan stres, sehingga tidak dapat diketahui berapa lama dan kuat paparan stres pada subyek penelitian. Penelitian Kivimaki dkk. (2005) mendapatkan bahwa semakin lama dan kuat paparan stres maka risiko terjadinya parameter sindrom metabolik semakin meningkat. ${ }^{16}$

Hubungan negatif lemah ini menunjukkan hasil sebaliknya dengan penelitian Kivimaki dkk. (2005). ${ }^{16}$ Diketahui bahwa besar sampel mempengaruhi kuatnya hubungan antar variabel, di mana pada penelitian ini jumlah subyek penelitian yang ikut penelitian lebih sedikit dari besar sampel $(91,43 \%)$. Rerata tingkat stres subyek penelitian adalah ringan, sehingga apabila dihubungkan dengan risiko parameter sindrom metabolik didapatkan hubungan yang lemah. Hal ini karena dalam pengukuran tingkat stres subyek penelitian cenderung kurang teliti mengisi kuesioner karena keterbatasan waktu yang dimiliki.

Didapatkan hubungan negatif sedang antara berat badan dan kadar HDL yang secara statistik signifikan, sedangkan berdasarkan tinggi badan, didapatkan hubungan negatif kuat antara tinggi badan dan kadar HDL yang secara statistik signifikan. Sementara itu berdasarkan IMT, didapatkan hubungan lemah antara IMT dan risiko pada parameter sindrom metabolik, yang secara statistik tidak signifikan. Hubungan negatif yang signifikan antara berat badan dan tinggi badan dengan kadar HDL menggambarkan terdapat hubungan terbalik antar kedua variabel tersebut, walaupun tidak menggambarkan risiko pada parameter sindrom metabolik.

Pengukuran status gizi berdasarkan berat badan, tinggi badan dan IMT menggambarkan status gizi secara umum. ${ }^{17}$ Diketahui bahwa IMT lebih menggambarkan hubungan dengan risiko pada parameter sindrom metabolik dibandingkan hanya berat badan dan tinggi badan karena menggunakan perbandingan dua variabel. Rerata IMT subyek penelitian adalah obese I $\left(27,49 \mathrm{~kg} / \mathrm{m}^{2}\right)$, di mana diketahui obese I sangat berisiko mengalami parameter sindrom metabolik.18

Didapatkan hubungan positif kuat antara lingkar perut dan kadar trigliserida yang secara statistik signifikan. Rerata lingkar perut subyek penelitian didapatkan normal $(89,43 \mathrm{~cm})$, dan dilihat dari IMT didapatkan obese I, keadaan ini menggambarkan obesitas sentral. Diketahui bahwa pada obesitas sentral didapatkan keadaan dislipidemia yang menggambarkan simpanan lemak tubuh yang berlebih sehingga meningkatkan risiko pada parameter sindrom metabolik. ${ }^{19-20}$

Kadar trigliserida menggambarkan simpanan lemak tubuh terutama pada obesitas sentral sebagai salah satu risiko pada parameter sindrom metabolik. Hasil penelitian ini mendukung hasil penelitian Steptoe dkk. (1999), di mana semakin besar lingkar perut didapatkan kadar trigliserida semakin tinggi. ${ }^{21}$ 
Berdasarkan tebal lemak suprailiaka, didapatkan hubungan negatif kuat antara tebal lemak suprailiaka dan kadar HDL yang secara statistik signifikan. Tebal lemak suprailiaka menggambarkan simpanan lemak subkutan pada regio abdomen. Diketahui bahwa semakin besar lingkar perut maka tebal lemak suprailiaka semakin besar. Semakin besar tebal lemak suprailiaka maka risiko sindrom metabolik semakin meningkat. Hasil penelitian menunjukkan hubungan status gizi dengan risiko sindrom metabolik secara statistik signifikan, namun belum dapat dikatakan mendukung secara klinis karena minimal tiga faktor risiko harus terpenuhi.

Paparan stres dalam waktu lama dan kuat, diketahui terjadi perubahan gaya hidup, salah satunya pemilihan jenis makanan lebih banyak mengandung energi dalam jumlah besar karena terbatasnya waktu untuk mengatur pola makan sehat. Makanan dengan kalori tinggi terdiri dari karbohidrat sederhana dan lemak trans yang diketahui dapat meningkatkan risiko sindrom metabolik. Jenis makanan ini juga memiliki efek relaksasi di mana efek yang ditimbulkan adalah menghambat sekresi hormon corticotropin releasing factor (CRF). Hambatan ini dapat menimbulkan rasa nyaman pada keadaan stres.

Selain itu, sering menunda makan siang meningkatkan porsi makan malam. Keadaan tersebut dapat menimbulkan obesitas yang diketahui meningkatkan risiko pada parameter sindrom metabolik. $22-23$

Pada hasil penelitian didapatkan hubungan positif sedang antara berat badan, IMT dan lingkar perut dengan rasio trigliserida dan $\mathrm{HDL}$ yang secara statistik signifikan. Rasio trigliserida dan HDL menunjukkan derajat pembentukkan plak aterosklerosis pada dinding pembuluh darah, dimana semakin besar rasio maka semakin besar risiko terbentuknya plak aterosklerosis.

Lingkar perut dan IMT merupakan variabel yang lebih menggambarkan risiko pada paramater sindrom metabolik dibandingkan berat badan saja. Demikian juga halnya dengan risiko terhadap pembentukkan plak aterosklerosis. Semakin besar lingkar perut maka semakin besar risiko terbentuknya plak aterosklerosis, demikian juga dengan IMT.

\section{SIMPULAN DAN SARAN}

Pada penelitian ini, dapat disimpulkan bahwa didapatkan hubungan negatif antara tingkat stres dengan sindrom metabolik, hubungan negatif antara berat badan dan kadar $\mathrm{HDL}$, dan hubungan negatif antara tinggi badan dan kadar HDL. Selain itu, didapatkan hubungan positif antara lingkar perut dan kadar trigliserida, dan hubungan positif antara berat badan, IMT dan lingkar perut dengan rasio trigliserida dan HDL. Walaupun didapatkan hubungan status gizi dengan risiko sindrom metabolik secara statistik signifikan, namun belum dapat dikatakan mendukung secara klinis.

Untuk mendapatkan hasil yang mendukung secara klinis, maka disarankan perlu dilakukan penelitian dengan rancangan berbeda dan dengan jumlah sampel yang lebih besar untuk dapat menjelaskan hubungan sebab akibat. Selain itu, perlu dilakukan pemeriksaan kadar hormon kortisol sebagai salah satu parameter tingkat stres yang objektif.

\section{RUJUKAN}

1. Spector PE. Employee Control and Occupational Stress. Psychological Science. 2002;11: 133-6.

2. Cornier MA, Dabelea D, Hernandez TL, Lindstrom RC, Steig AJ, Stob NR, Pelt REV, Wang H, Eckel RH. The Metabolic Syndrome. Endocrine Reviews. 2008;29(7): 777-822.

3. Chandola T, Brunner E, Marmot M. Chronic Stres at Work and The Metabolic Syndrome: Prospective Study. British Medical Journal. 2006; 332(7540): 1-5.

4. National Institutes of Health. The Third Report of the National Cholesterol Education Program Expert Panel on Detection, Evaluation, and Treatment of High Blood Cholesterol in Adult. Bethesda: National Institutes of Health, 2001. Dalam:http://www.nhlbi.nih.gov/guidelines/c holesterol/ index.htm. (diakses 20 Mei 2006).

5. Kouvanen A, Kivimaki M, Cox SJ, Cox T, Vahtera J. Relationship Between Work Stress and Body Mass Index Among 
45.810 Female and Male Employees. Psychosomatic Medicine. 2005;67:557-83.

6. Ignarro LJ, Balestrieri ML, Napoli C. Nutrition, Physical Activity, and Cardiovascular Disease: An Update. Cardiovascular Research. 2007;73:326-40.

7. Shilder RJ, Marden JH. Metabolic Syndrome and Obesity in an Insect. PNAS. 2006;103(49):18805-9.

8. Vega GL. Obesity, The Metabolic Symdrome, and Cardiovascular Disease. Am Heart J. 2001; 142: 1108-16.

9. Madiyono B, Moeslichan S, Sastroasmoro S, Budiman I, Purwanto HS. Perkiraan Besar Sampel. Dalam: Sastroasmoro S, dan Ismael S, editor. Dasar-Dasar Metodologi Penelitian Klinis. Edisi ke-2. Jakarta: Sagung Seto. 2002. hal.269.

10. Montoye HJ, Kemper HCG, Saris WHM, Washburn RA. Measuring Physical Activity and Energy Expenditure. In: Human Kinetics. S.I: s.n,1996.

11. Supriyadi. Kuesioner Indeks Stres. Laboratorium Perilaku Fakultas Kedokteran Universitas Udayana. Denpasar: FK Udayana, 2004.

12. Gibson RS. Principles of Nutritional Assessment. $2^{\text {nd }}$ edition. New York: Oxford University Press. 2005.p.273-93.

13. Bjorntorp P. Heart and Soul: Stress and The Metabolic Syndrome. Scand Cardiovasc J. 2001;35:172-7.

14. Chandola T, Britton A, Brunner E, Hemingway $\mathrm{H}$, Malik M, Kumari $\mathrm{M}$, et al. Work Stress and Coronary Heart Disease: What Are The Mechanism?. European Heart Journal. 2008;29:640-8.

15. Haas JD, Brownlie T. Iron Deficiency and Reduced Work Capacity: A Critical Review of the Research to Determine a Causal Relationship. J Nutr. 2001;131:676S-90S.

16. Kivimaki $M$, Leino-Arjas $P$, Luukkonen $R$, Riihimki $\mathrm{H}$, Vahtera J, Kirjonen J. Work stress and risk of cardiovascular mortality: prospective cohort study of industrial employees. BMJ. 2002;325:857-60.

17. Dwyer JT. Nutrition Guidelines and Education of the Public. J Nutr. 2001;131: 3074S-7S.

18. WHO-WPRO.The Asia-Pacific Perspective: Redefining Obesity and Its Treatment. Health Communications Australia. 2002.p.22. Dalam http://www.diabetes.com (diakses tanggal 16 Januari 2009).

19. Misra A, Khurana L. Obesity and the Metabolic Syndrome in Developing Countries. J Clin Endrocrinol Metab. 2008;93:S9-S30.

20. Rector RS, Warner SO, Liu Y, Hinton PS, Sun GY, Cox RH, et al. Exercise and Diet Induced Weight Loss Improves Measures of Oxidative Stress and Insulin Sensitivity in Adults With Characteristic of the Metabolic Syndrome. Am J Physiol Endocrinol Metab. 2007;293:E500-6.

21. Steptoe A, Cropley M, Griffith J, Joekes K. The influence of abdominal obesity and chronic work stress on ambulatory blood pressure in men and women. Int $J$ Obes. 1999;23:1184-91.

22. Vitaliano PP, Scanlan JM, Zhang J, Savage MV, Hirsch IB, Siegler IC. A Path Model of Chronic Stress, The Metabolic Syndrome, and Coronary Heart Disease. Psychosomatic Medicine. 2002;64: 418-35.

23. Oliver G, Wardle J, Gibson EL. Stress and Food Choise: A Laboratory Study. Psychosomatic Medicine. 2000;62: 853-65. 